\title{
The theoretical model of formation of readiness of future teachers of physical education in the organization of extracurricular activities on tourism
}

\section{Теоретична модель формування готовності майбутніх учителів фізичної культури до організації позакласної роботи з туризму}

\author{
Chalii Liudmyla \\ Чалій Людмила Володимирівна
}

Rivne State Humanitarian University, Ukraina

Рівненський державний гуманітарний університет, Рівне

Keywords: model; future teachers of physical education; extracurricular work; tourism; readiness; Ключові слові: модель; майбутні учителі фізичної культури; позакласна робота; туризм; готовність,

\begin{abstract}
The article presents a theoretical model of readiness of the future teacher of physical education in the organization of extracurricular activities on tourism as a system of four interconnected blocks: conceptual, content, technological and effective - correctional. Conceptual block contains the purpose, a list of tasks, general scientific approaches and principles of teaching. The purpose of the article is to determine and justify the component model of readiness of the future teacher of physical education in the organization of extracurricular activities with tourism. Content block models constitute the professionally oriented and sports-pedagogical discipline.Technological block of model of readiness of the future teacher of physical education in the organization of extracurricular activities on tourism comprises the steps of the model realization (preparatory, operating, diagnostic - effective), pedagogical conditions of formation of readiness of the future teacher of physical education in the organization of extracurricular activities in tourism and technology of their implementation. Effective - correctional block contains the structural components (motivational - orientation, cognitive, practical and personal), criteria (axiological, epistemological, operational and integrational) and levels (high, medium, basic and low) of formation of readiness of the future teacher of physical education in the organization of extracurricular activities in tourism.

Pedagogical conditions of formation of future teachers of physical education in the organization of extracurricular activities with tourism are identified as: formation of future physical education teachers'
\end{abstract}


motivational systems to implement extracurricular activities of tourism which are based on consideration of their individual psychological characteristics; strengthening of semantic saturation of the educational process of formation of future physical education in the organization of extracurricular activities in tourism by introducing a variable subject "The organization of extracurricular activities on tourism" and addition of the content of other disciplines with relevant modules; provision of modern information and methodological support of the educational process of formation of future physical education teachers for extracurricular activities in tourism. The set of components of the educational process, designed to ensure the implementation of the pedagogical conditions and to achieve the goal of forming the future teachers of physical education in the organization of extracurricular activities with tourism was justified.

\begin{abstract}
Анотація
У статті автор представила теоретичну модель формування готовності майбутнього учителя фізичної культури до організації позакласної роботи з туризму як систему чотирьох взаємопов'язаних блоків: концептуальний, змістовий, технологічний та результативно-корекційний. Концептуальний блок містить мету, перелік завдань, загальнонаукові підходи і принципи навчання. Метою наукової статті було визначення та обгрунтування складових моделі формування готовності майбутнього учителя фізичної культури до організації позакласної роботи з туризму. Змістовий блок моделі складають зміст професійно-орієнтованих та спортивно-педагогічних дисципліни. Технологічний блок моделі формування готовності майбутнього учителя фізичної культури до організації позакласної роботи з туризму включає етапи реалізації моделі (підготовчий, операційний, діагностико-результативний), педагогічні умови формування готовності майбутнього учителя фізичної культури до організації позакласної роботи з туризму та технологію їх реалізації. Результативно-корекційний блок складають структурні компоненти (мотиваційно-орієнтаційний, когнітивний, практичний i особистісний), критерії (аксіологічний, гносеологічний, операційний та інтеграційний) та рівні (високий, середній, базовий та низький) сформованості готовності майбутнього учителя фізичної культури до організації позакласної роботи з туризму. Педагогічними умовами формування готовності майбутніх учителів фізичної культури до організації позакласної роботи з туризму визначено: формування у майбутніх учителів фізичної культури мотиваційних установок щодо здійснення позакласної роботи з туризму, що базується на врахуванні їх індивідуально-психологічних особливостей; посилення змістової насиченості навчально-виховного процесу формування готовності майбутніх учителів фізичної культури до організації позакласної роботи з туризму за рахунок введення варіативної дисципліни «Організація позакласної роботи 3 туризму» та доповнення змісту інших навчальних дисциплін відповідними модулями; забезпечення сучасного інформаційно-методичного супроводу навчальновиховного процесу формування готовності майбутніх учителів фізичної культури до організації позакласної роботи з туризму. Обгрунтовано сукупність компонентів освітнього процесу, що покликані забезпечити реалізацію педагогічних умов та досягнення поставленої мети щодо формування готовності майбутнього учителя фізичної культури до організації позакласної роботи 3 туризму.
\end{abstract}

\title{
Вступ
}

Організація туристської діяльності зі школярами як педагогічний процес підпорядковується цілій низці нормативно-правових актів: Закон України «Про туризм» (1995, зі змінами 2015р.), Закон України «Про Загальнодержавну соціальну програму розвитку фізичної культури і спорту на 2013-2017 роки» (2013), Указ Президента України «Національна стратегія розвитку освіти в Україні на період до 2021 року» (2013), Закон України «Про вищу освіту» (2014) та інші законодавчі акти щодо фізичної культури і спорту.

Концептуальні положення формування готовності майбутніх учителів фізичної культури стали предметом наукових досліджень В. Баркасі, М. Васильєва, О. Вознюк, I. Дроздова, Н. Зубанової, Р. Карпюка, Л. Шевчук та ін. Можемо відзначити належну увагу вчених до питання моделювання у педагогічній науці. Проблему розглядають багато дослідників, серед них: С. Архангельський, В. Афанасьєв, Н. Кузьміна, Є. Лодатко, Ю. Мельник, І. Ніколаєску, І. Новік， В. Ортинський, О. Столяренко, С. Томенчук та інші. Проблемами моделей педагогічних процесів займалися Ю. Васьков, О. Винославська, Л. Серман Н. Тализін та ін. 


\section{Мета}

У нашому дослідженні ми поставили мету дослідити та обгрунтувати складові моделі формування готовності майбутнього учителя фізичної культури до організації позакласної роботи з туризму.

\section{Матеріал та методи дослідження.}

Поряд 3 поняттям «модель» широко використовується ще один термін «моделювання». Низка вчених розглядає моделювання як метод, що забезпечує вибір оптимальних засобів вирішення проблеми [5].

Є. І. Жуковський зробив висновок, що готовність майбутніх фахівців фізичної культури до організації самостійної фізкультурно-оздоровчої діяльності школярів буде успішною, якщо модель буде містити такі компоненти: мотиваційний, гностичний, технологічний, рефлексивний [2].

У роботі ми врахували бачення Л. Ю. Дудорової, яка у експериментальній моделі готовності майбутніх учителів до професійно-туристичної діяльності віділляє такі блоки: цільовий (постановка конкретної мети та завдань, вивчення навчального матеріалу); концептуальний (визначення наукових підходів та принципів вивчення системи важливих наукових положень і використання їх у навчанні студентів; оптимальний підбір дисциплін навчального плану, змістовність навчальних програм, продуманість змісту навчальних занять); змістово-процесуальний (педагогічні умови, зміст, форми і методи, що спонукають студента до активної навчальнопізнавальної, професійної діяльності, формують у них позитивну мотивацію цієї діяльності; добір прийомів, методів та організаційних форм навчання, оптимальне поєднання колективної, групової та індивідуальної роботи із засвоєння студентами змісту дисциплін і навчального матеріалу, вироблення в них відповідних умінь та навичок); результативний (компоненти та рівні сформованості готовності; контроль за засвоєнням студентами знань, набуттям умінь і навичок, внесення необхідних коректив до змісту i методики навчання 3 метою підвищення ефективності; виявлення рівня знань, умінь і навичок кожного студента, причин неуспішності в кожному конкретному випадку i відповідна робота щодо їх усунення) [1].

Отже, на основі аналізу наукових джерел, з врахуванням характеру позакласної роботи з туризму, ми розробили модель формування готовності майбутніх вчителів фізичної культури до організації позакласної роботи з туризму, яка включає концептуальний, змістовий, технологічний та результативно-корекційний блоки (рис. 1).

У концептуальний блок входять: постановка мети, завдань, загальнонаукові підходи і принципи навчання.

Метою реалізації моделі є формування готовності майбутнього учителя фізичної культури до організації позакласної роботи з туризму.

Завдання підпорядковані меті та полягають у наступному:

- сформувати інтерес та позитивну мотивацію студентів до позакласної роботи з туризму, заснованих на усвідомлені ролі і місця туризму в шкільному освітньому середовищі;

- сформувати у студентів систему технологічних знань, вмінь та навичок позакласної роботи з туризму та досвіду їх практичного застосування;

- с сформувати професійні особистісні якості студентів для успішної організації позакласної роботи з туризму.

У моделі формування готовності майбутніх вчителів фізичної культури до організації позакласної роботи з туризму методологічною базою визначено аксіологічний, компетентнісно-діяльнісний та системний підходи. 


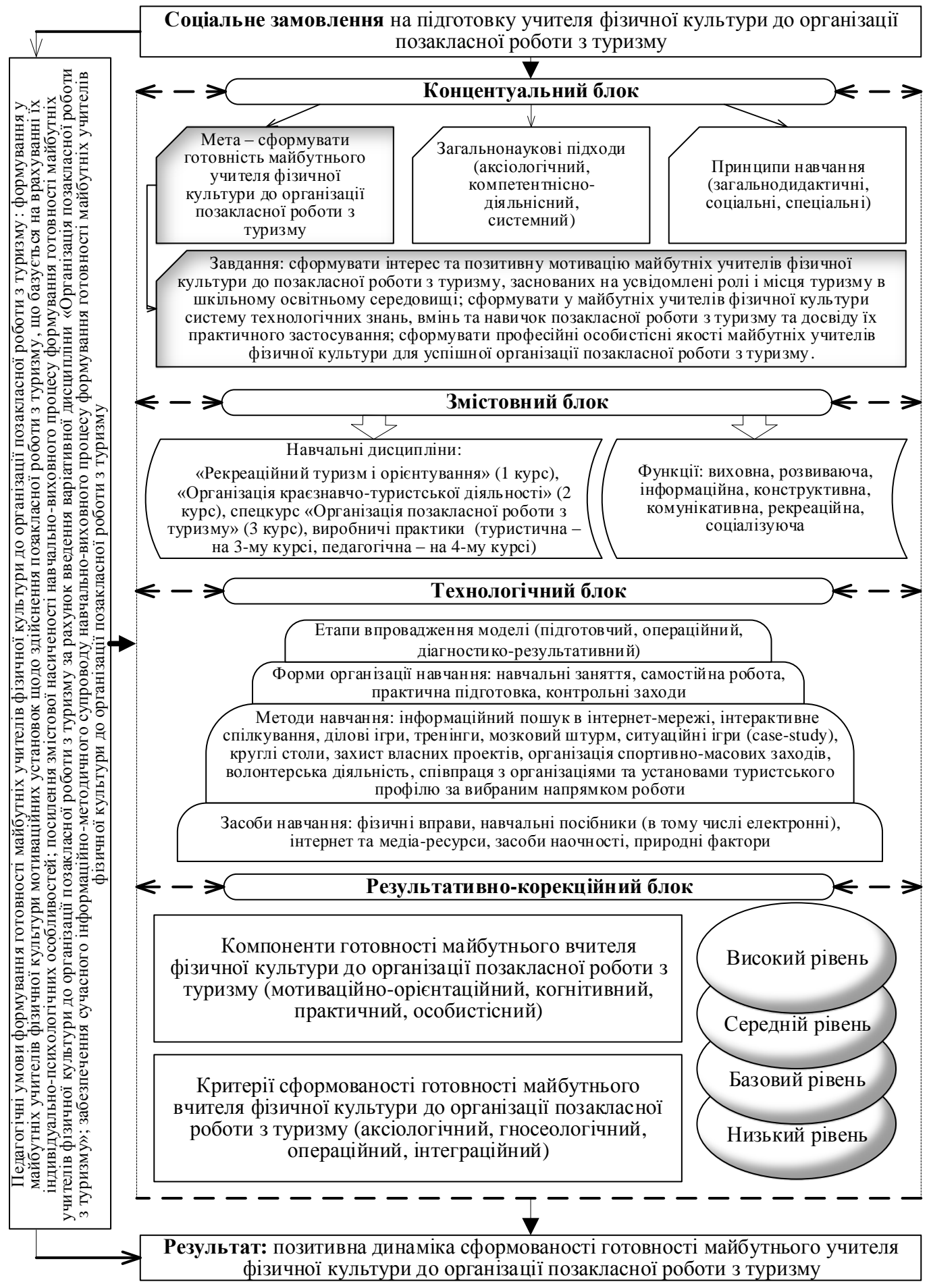

Рис. 1. Модель формування готовності майбутнього учителя фізичної культури до організації позакласної роботи з туризму

Аксіологічний niдxiд (І. Д. Бех, О. І. Вишневський, І. А. Зязюн, В. О. Сластьонін, О. В. Сухомлинська, С. С. Вітвицька та ін.) у нашому дослідженні забезпечує: формування у майбутнього учителя фізичної культури ставлення до самого себе як до професіонала та як до людини - найвищої цінності суспільства; набуття системи знань про сутність і природу шкільного туризму, розвиток ціннісного ставлення до природи та середовища шкільного соціуму; розуміння мети професійної підготовки - формування гуманістичної філософії особистості, спрямованої на пошук гармонії у світі та прагнення добра. Дотримуючись аксіологічного підходу у процесі формування готовності майбутніх вчителів фізичної культури до організації позакласної роботи з туризму, ми маємо змогу продемонструвати зв'язок туризму 3 соціально значущими цінностями; виявити 
те позитивне, що продукує туризм, і на що потрібно орієнтуватися; використовувати шкільний учнівський колектив як засіб формування позитивного соціального досвіду.

Компетентнісно-діяльнісний підхід (Б. Г. Ананьєв, І. О. Зимня, О. О. Леонтьєв, С. Л. Рубінштейн та ін.) необхідний у процесі формування готовості майбутнього учителя фізичної культури для досягнення освітнього результату, що включає не лише суму знань, умінь та навичок, але й демонструє розвиток особистості, що здобула через процес практичної діяльності здібності та можливості діяти у професійному середовищі, впевнено вирішувати різноманітні соціальні завдання. У нашій роботі цей підхід визначає підготовленість до майбутньої професійної діяльності та формування індивідуальної педагогічної техніки майбутніх учителів фізичної культури щодо організації туристичних заходів у позанавчальний час.

Системний niдxiд (О. Л. Кононко, І. В. Малафіїк, Г. О. Підкурганна Ю. О. Шабанова та ін.) необхідний для розуміння та аналізу всієї багатоаспектної діяльності педагога, встановлення залежності між попередніми та наступними діями, між елементами процесу навчання. Для нашого дослідження це стало основою комплексного вивчення процесу формування готовності майбутніх учителів фізичної культури до організації позакласної роботи 3 туризму як системи. Оскільки компоненти будь-якої системи знаходяться у тісному взаємозв'язку, то зміни одного із компонентів зумовлять зміни всієї системи. Цей підхід у нашому дослідженні дозволяє поєднати в одне ціле об'єкт та суб'єкт дослідження, мету, зміст, організаційно-педагогічні умови, технологію навчання та результат. Завдяки цьому підходу 3'являється можливість кваліфіковано управляти педагогічним процесом, аналізувати механізми формування готовності майбутніх учителів фізичної культури.

Формування готовності відбувається у процесі професійної підготовки за правилами та нормами, які носять назву принципів навчання. В.В.Ягупов справедливо зазначає, що принципи навчання потрібно розуміти як «спрямовуючі положення, нормативні вимоги до організації та проведення дидактичного процесу» [7].

Для нас важливо було віднайти принципи, які ефективні при підготовці до туристичної діяльності. Результатом пошуку стали принципи організації спортивного туризму, сформовані С. П. Фокіним: принцип поєднання туризму, краєзнавства й екології (буття в природному середовищі вимагає пізнання цього середовища; пізнання рідного краю, його історії, культури, місцевих звичаїв, виховує патріотизм у людини, любов і шану до своєї Батьківщини; при цьому туристсько-краєзнавча робота неможлива без поєднання з екологічним вихованням людини); принцип поступового освоєння навколишнього світу (перші мандри треба починати зі свого рідного краю; освоєння проходить завжди комплексно, вивчається історія, культура, природа і господарство району подорожі, що дає можливість одержати більш повне уявлення про регіон, подорожі); принцип поступового набуття туристського досвіду (принцип забезпечує досягнення рівня туристської майстерності та досвіду туристів, що необхідно для безпечного проходження спортивного походу); принцип туристсько-краєзнавчих циклів (цикли розташовуються на гносеологічній спіралі освоєння навколишнього світу; здійснюється поступове розширення регіонів подорожей і їхнє краєзнавче пізнання та туристсько-спортивне освоєння); принцип посадової структури самоврядування туристської групи (окрім отримання важливих життєвих навичок і значного розширення кругозору, туристи одержать найцінніші навички ділової взаємодії, маючи змогу вступати у стосунки відповідальної залежності із товаришами і педагогами; похідні посади згуртовують туристській колектив, створюють умови ділової, організованої взаємодії туристів, дисциплінують їх, займають вільний час відповідальною громадською діяльністю; окрім того, вони $є$ основою самоврядування в похідній туристській групі, допомагають керівникові подорожі 
доцільно організовувати життя туристського колективу); від норм і правил туристської групи до Глобального етичного кодексу туризму (цей принцип на основі традицій, норм і правил спілкування і життєдіяльності у туристській групі дозволяє формувати моральні, етичні загальнолюдські цінності особистості) [4].

Визначаючи принципи навчання, ми керувалися основами теорії і методики фізичного виховання, системою традиційних загальнонаукових дидактичних принципів та змістом позакласної роботи з туризму:

- загальнодидактичні принципи (свідомості й активності, наочності, доступності та індивідуалізації, системності);

- соціальні принципи (гармонійного розвитку особистості, зв'язку з життєдіяльністю, оздоровчої спрямованості);

- спеціальні (поєднання туризму i краєзнавства, поступового набуття туристського досвіду, етичного кодексу туризму, психологічного комфорту, культивування успіху).

Принцип свідомості й активності необхідний у процесі формування готовності майбутнього учителя фізичної культури як умова та гарантія набуття професійних знань, умінь та навичок через активну взаємодію суб'єктів навчально-виховного процесу.

Принциип наочності на основі споглядання та осмислення побаченого полегшує процес навчання та формує свідоме відношення до професійної діяльності щодо організації позакласної роботи з туризму.

За умови дотримання принцииу доступності та індивідуалізащії навчання майбутній учитель фізичної культури засвоїть основи позакласної роботи з туризму, 3 розумінням поставиться до своїх можливостей та отримає мотивацію до пошуку максимального використання отриманого професійного багажу.

Принции системності у навчанні майбутнього учителя фізичної культури забезпечує розгляд системи позакласної роботи з туризму як об'єкта навчання, послідовність та зв'язок усіх дисциплін професійного спрямування.

Принциип гармонійного розвитку особистості у нашому дослідження спрямований на поєднання фізичного розвитку студента через активну туристську діяльність з розумовим, естетичним, моральним вихованням.

Принцип зв'язку з життєдіяльністю у процесі формування готовності майбутнього учителя фізичної культури реалізується через формування туристських вмінь та навичок, що $є$ необхідними та корисними у житті, особливо важливі навички самообслуговування.

Принцип оздоровчої спрямованості якнайкраще забезпечується заняттями, що проходять у природніх умовах з дотриманням усіх вимог до організації фізичного виховання. Таким чином, у туристську діяльність, що $є$ найоптимальнішою формою оздоровчих занять, закладено можливість реалізації цього принципу.

Принции поєднання туризму $і$ краєзнавства сприяє різносторонньому розвитку особистості студента, виховує високі почуття патріотизму та гордості за свою країну.

Принции поступового набуття туристського досвіду забезпечує правильну організацію позакласної роботи з туризму учителем фізичної культури відповідно до нормативно-правових регулюючих актів.

Принции етичного кодексу туризму необхідний для створення позитивної атмосфери всередині туристського колективу та для встановлення норм поведінки і спілкування з оточуючими.

Принцип психологічного комфорту беруть як основу взаємодії суб'єктів навчально-виховного процесу та як засіб сприяння позитивному мікроклімату в студентському колективі.

Принцип культивування успіху активізує задоволення від своєї праці - це умова формування емоційного аспекту готовності майбутнього учителя до професійної діяльності. 
Змістовий блок моделі формування готовності майбутнього учителя фізичної культури до організації позакласної роботи 3 туризму складають: зміст професійно-орієнтованих та спортивно-педагогічних дисципліни (знання, вміння та навички, що забезпечують формування готовності майбутнього учителя фізичної культури до організації позакласної роботи з туризму), функції моделі.

Навчальні дисципліни, такі як «Рекреаційний туризм і орієнтування», «Організація краєзнавчо-туристської діяльності», спецкурс «Організація позакласної роботи 3 туризму» та виробничі практики (туристична, педагогічна) закладають основи формування готовності майбутнього учителя фізичної культури до організації позакласної роботи з туризму.

Створена нами модель формування готовності майбутнього учителя фізичної культури до організації позакласної роботи з туризму виконує наступні функції:

- виховну (формування системи цінностей у майбутніх учителів фізичної культури засобами туризму, підтримка та розвиток професійно важливих якостей та позитивних рис характеру майбутнього учителя);

- розвиваючу (розвиток інтелектуальних та професійно-орієнтованих здібностей та гуманістичного світогляду майбутніх учителів фізичної культури, які є необхідними для ефективної позакласної роботи з туризму, розвиток фізичних якостей майбутніх учителів фізичної культури у процесі активних занять туризмом);

- інформаційну (створення інформаційної платформи для забезпечення процесу формування готовності майбутнього учителя фізичної культури через постійний моніторинг навчально-методичного ресурсу педагогіки, поінформованість майбутніх учителів фізичної культури про інновації у педагогіці, про передовий досвід в галузі);

- конструктивну (забезпечення майбутніх учителів фізичної культури вміннями планування, організації та проведення позакласної роботи 3 туризму, співпраці 3 спонсорами, громадськими організаціями та державними установами),

- комунікативну (розвиток комунікативних умінь майбутнього учителя фізичної культури щодо спілкування з учнями у форматі довіри, співпраці, налагодження позитивних стосунків 3 педагогічним колективом школи, з батьками);

- рекреаційну (відновлення та підтримка розумової, фізичної працездатності майбутніх учителів фізичної культури засобами туризму та демонстрація можливостей туризму у формуванні здорового способу життя);

- соціалізуючу (підготовка майбутніх учителів фізичної культури до самостійного життя через участь у туристських подорожах, через систему позааудиторної роботи та ін.).

Технологічний блок моделі формування готовності майбутнього учителя фізичної культури до організації позакласної роботи з туризму складають етапи реалізації моделі (підготовчий, операційний, діагностико-результативний), педагогічні умови формування готовності майбутнього учителя фізичної культури до організації позакласної роботи з туризму та технологія їх реалізації (форми організації навчання студентів, засоби та методи навчання).

На підготовчому етапі ми ознайомлюємо майбутніх учителів фізичної культури 3 основами педагогічної діяльності, з особливостями роботи учителя фізичної культури, 3 нормативно-правовою базою 3 туризму та вимогами до позакласної роботи 3 туризму. На даному етапі відбувається формування ціннісно-мотиваційних установок та усвідомлення характеру майбутньої діяльності.

Операційний етап покликаний озброїти майбутніх учителів фізичної культури тими вміннями та навичками, що дають можливість організувати різноманітні заходи з туризму у системі позакласної роботи. Завдання етапу реалізуються через аудиторні заняття та практичні заняття на місцевості, особливе значення має 
туристична практика. Таким чином, формується досвід організації позакласної роботи 3 туризму для якісного виконання професійних функцій педагога у майбутньому.

Діагностико-результативний етап дотичний до операційного та дозволяє контролювати практичну сторону процесу формування готовності майбутнього учителя фізичної культури до організації позакласної роботи з туризму, підвести підсумки впровадження моделі у навчально-виховний процес вищого навчального закладу та означити рівень сформованості готовності майбутнього учителя фізичної культури до організації позакласної роботи з туризму.

Аналіз наукової літератури та матеріалів педагогічних досліджень виявив відсутність розвідок стосовно педагогічних умов формування готовності майбутнього учителя фізичної культури до організації позакласної роботи 3 туризму. У літературних джерелах ми зустріли дотичні о нашого дослідження розвідки стосовно педагогічних умов формування готовності майбутніх фахівців зі спортивно-оздоровчого туризму до професійної діяльності та умови формування готовності бакалаврів туризму до роботи в сфері активного відпочинку $[3,6]$.Тому одним із завдань нашого дослідження була теоретична розробка та обгрунтування педагогічних умов формування готовності майбутнього учителя фізичної культури до організації позакласної роботи з туризму.

Успіх формування готовності майбутнього учителя фізичної культури до організації позакласної роботи 3 туризму залежить від реалізації таких педагогічних умов:

- формування у майбутніх учителів фізичної культури мотиваційних установок щодо здійснення позакласної роботи з туризму, що базується на врахуванні їх індивідуально-психологічних особливостей;

- посилення змістової насиченості навчально-виховного процесу формування готовності майбутніх учителів фізичної культури до організації позакласної роботи з туризму за рахунок введення варіативної дисципліни «Організація позакласної роботи з туризму» та доповнення змісту інших навчальних дисциплін відповідними модулями;

- забезпечення сучасного інформаційно-методичного супроводу навчальновиховного процесу формування готовності майбутніх учителів фізичної культури до організації позакласної роботи з туризму.

Результативність реалізації педагогічних умов пов'язана 3 ініціативністю, активністю, творчістю та фаховою майстерністю викладачів вищих закладів освіти та відповідного матеріального забезпечення освітнього процесу у вищій школі.

Форми організації навчання, використані нами у процесі формування готовності майбутнього учителя фізичної культури до організації позакласної роботи з туризму - це навчальні заняття, самостійна робота, практична підготовка, контрольні заходи. Основними видами навчальних занять було визначено лекцію, лабораторні, практичні, індивідуальні заняття, консультації.

Для досягнення високого результату у формуванні готовності майбутніх вчителів фізичної культури до організації позакласної роботи з туризму окрім традиційних методів навчання у вищій школі (методи організації діяльності тих, кого навчають; методи стимулювання діяльності; методи перевірки й оцінки) у моделі формування готовності майбутнього учителя фізичної культури до організації позакласної роботи 3 туризму виокремлено такі методи навчання: інформаційний пошук в інтернет-мережі, інтерактивне спілкування, ділові ігри, тренінги, мозковий штурм, ситуаційні ігри (case-study), круглі столи, захист власних проектів. Актуальними є наступні методи навчання: організація спортивно-масових заходів, волонтерська діяльність, співпраця 3 різноманітними організаціями та установами за вибраним напрямком роботи.

Засоби навчання - це фізичні вправи, навчальні посібники (в тому числі електронні), інтернет та медіа-ресурси, засоби наочності, природні фактори. 
Результативно-корекиійний блок відображає структуру, критерії та рівні сформованості готовності майбутнього учителя фізичної культури до організації позакласної роботи з туризму. До компонентів готовності майбутнього учителя фізичної культури до організації позакласної роботи 3 туризму віднесено мотиваційно-орієнтаційний, когнітивний, практичний і особистісний.

Основою вибору критеріїв є зміст навчальних програм та специфіка виду занять, тому введено такі критерії оцінювання рівня сформованості готовності майбутнього учителя фізичної культури до організації позакласної роботи 3 туризму: аксіологічний, гносеологічний, операчійний та інтеграиійний. Рівнями сформованості готовності майбутніх учителів фізичної культури до організації позакласної роботи з туризму визнано високий, середній, базовий та низький.

\section{Висновки}

Таким чином, запропонована модель формування готовності майбутнього учителя фізичної культури до організації позакласної роботи 3 туризму утворює систему, що поєднує на основі загальної мети концептуальний, змістовний, технологічний та результативно-корекційний блоки та забезпечує кінцевий результат - позитивну динаміку формування готовності майбутнього учителя фізичної культури до організації позакласної роботи з туризму. Послідовність та взаємодія блоків зазначеної моделі відтворюють досліджуваний процес та надають можливість експериментальної перевірки доцільності запропонованих педагогічних умов формування готовності майбутнього учителя фізичної культури до організації позакласної роботи з туризму.

\section{Список літератури.}

1. Дудорова Л.Ю. (2014). Модель формування готовності майбутніх учителів до професійнотуристичної діяльності. Вісник Чернігівського нац. пед. університету, 118(2), с. 116-119.

2. Жуковський Є.I. (2012). Формування готовності майбутніх учителів фізичної культури до організації самостійної фізкультурно-оздоровчої діяльності школярів. Фізичне виховання, спорт і культура здоров'я у сучасному суспільстві, 1(21), с. 40-43.

3. Коллегаєв М.Ю. (2013) Організаційно-педагогічні умови формування готовності бакалаврів 3 туризму до професійної діяльності в індустрії активного відпочинку. http://tourlib.net/statti_ukr/kollegaev.htm (доступ: 2016.12.29).

4. Фокін С.П. (2010). Туризмологічні аспекти спортивного туризму. Науковий вісник Інституту міжнародних відносин НАУ: Зб. наук. статей, 1, с. 207-213.

5. Чалій Л.В. (2014). Сучасні підходи до складання моделей підготовки фахівців із фізичної культури. Фіз. виховання, спорт і культура здоров'я у сучас. сусп-ві : зб. наук. пр. Східноєвроп. нац. ун-ту ім. Лесі Українки, 3 (27), с. 18-21.

6. Шафранський В.В. (2009) Педагогічні умови формування готовності у майбутніх фахівців зі спортивно-оздоровчого туризму до професійної діяльності. Педагогіка і психологія, 491, c.191-200.

7. Ягупов В.В. (2002). Педагогіка: навчальний посібник. http://eduknigi.com/ped_view.php?id=36 (доступ: 2017.01.12). 